\title{
DESCRIPTIONS OF TINEOID MOTHS (MICROLEPIDOPTERA) FROM SOUTH AMERICA.
}

\author{
By August Busck,
}

Of the Bureau of Entomology, U. S. Department of Agriculture.

The U. S. National Museum is indebted to Mr. William Schaus for the material on which the following paper is based, as well as for the bulk of the Central and South American material of tineoid moths it possesses, which is considerable.

In the working up of this material the writer has carefully avoided any interference with Lord Walsingham's part of the Biologia Centrali-Americana, which is now in press or partly issued, and with the material for which the writer is thoroughly familiar. For this reason very many new species and genera from South America, now contained in the National Museum, were passed by and these remain to be described when the genera shall have been established by the publication of the Biologia.

In the identification of the forms already described from South America, Zeller's careful descriptions usually suffice to establish the identity of the species; Felder's species also may be recognized with reasonable certainty from his colored figures. Walker's numerous descriptions, on the other hand, are as a rule quite inadequate for recognition, but the writer has had the opportunity to study his types in the British Museum, and the National Museum has obtained carefully colored figures of these types, which proved a valuable aid in their identification.

\section{Family GELECHIIDÆ.}

\section{PLEUROTA LITERATELLA, new species.}

Plate 8, fig. 12 .

Labial palpi very long, typically Pleurota-formed, brown with whitish base. Face and tongue whitish. Head and thorax light brown. Forewings long, narrow, pointed, spear-shaped, light brown; dorsal half somewhat lighter and more yellowish than costal half and separated from it by an indistinct longitudinal streak of darker 
brown; at the end of the cell is a faint blackish shade, hardly discernible as two small black dots; on the middle of the wing are two small, well-defined ocher-yellow dots, edged with reddish scales, one on each side of vein $1^{\mathrm{b}}$; extreme dorsal edge ocherous towards base. Hindwings yellowish white. Abdomen above salmon red; underside and anal tufts yellowish white. Legs yellowish white, tufts on posterior tibiæ brown.

Alar expanse. $-32-38 \mathrm{~mm}$.

Habitat.-St. Jean, Maroni River, French Guiana. Wm. Schaus, collector.

Type.-Cat. No. 13557, U.S.N.M.

Cotype in British Museum.

A striking species typical of the genus in oral and venational characters, but with rather unusual narrow, spear-shaped forewings.

PSORICOPTERA APICEPUNCTA, new species.

Plate 9, fig. 35 .

Labial palpi light ocherous, mottled with brown. Antennæ brown with basal third deep black. Face ocherous. Head light brown. Thorax light brown; patagia with base black. Forewings light deer brown, finely mottled with indistinct, transverse, black striation; on the middle of the cell is a smali black, oblong spot, and at extreme apex is another deep black, very prominent, larger spot. Cilia light brown. Hindwings dark silky fuscous. Abdomen dark fuscous above, underside light brown. Legs ocherous brown.

Alar expanse. $-28 \mathrm{~mm}$.

Habitat.-Cayenne, French Guiana; Panama; Tuis, Turrialba, and Sixola River, Costa Rica. Wm. Schaus, collector.

Type.-Cat. No. 13558, U.S.N.M.

- Cotype in British Museum.

A striking, clear-cut species, typical of the genus and not mistakable for any other described species.

\section{Family CECOPHORIDA.}

FILINOTA, new genus.

Type-Filinota hermosella Busck.

Labial palpi long, recurved, reaching beyond the vertex; second joint slightly thickened with smoothly appressed scales; terminall joint long, but shorter than second, slim, smooth, pointed. Antennæ longer than the forewings, finely ciliated (1); basal joint without pecten. Tongue long, curled, scaled. Forewings long and narrow, nearly five times as long as broad; costa and dorsum nearly parallel; termen evenly rounded; apex bluntly pointed; 12 veins; 7 and 8 stalked; 7 to costa; 2 from before end of cell; 3 and 4 stalked from 
end of cell; $1^{\text {b }}$ furcate at base. Hindwings broader than the forewings; costa straight; dorsum and termen evenly rounded; apex rather pointed; 7 veins; 8 free; 6 and 7 parallel; 3 and 4 coincident; 5 approximate to $3+4$. Posterior tibiæ nearly smooth, slightly hairy above.

Closely related to the European genus Carcina Hübner, but further developed and differing in the narrow wings and the coincident veins 3 and 4 in the hindwings; also it has lost the pecten on the basal joint of the antennæ and vein 7 has reached the costal side of apex.

FILINOTA HERMOSELLA, new species.

Plate 8, fig. 7.

Labial palpi light golden yellow, touched exteriorly with carmine. Face and head straw yellow; collar carmine. Antennæ carmine with golden underside and basal joint and with pale yellow tip, preceded by a broad blackish band. Thorax golden yellow with central carmine spot. Ground color of the forewings bright carmine with golden yellow, blackish brown, and silvery white ornamentation; costal edge from near base to apex and terminal edge golden; on the dorsal edge are two silvery white spots, one at basal fourth continued up into a whitish yellow spot on the cell, the other triangular at apical third. Three small golden yellow dashes are found on basal half of the wing, one at the base, one just within the dorsal margin beyond the first silvery spot, and one following the continuation of that spot on the middle of the cell. On the middle of the apical part of the wing is a large conspicuous silvery white dash surrounded first by carmine, then by blackish brown scales, which latter are continued into long winding lines in the central part of the carmine, between the various white and golden spots. Cilia blackish brown. Hindwings paler carmine with golden cilia. Abdomen carmine above, yellow laterally and on the underside. Front legs carmine, annulated with black; hind legs yellow with a deep black, longitudinal line on first tarsal joint. Underside of wings bright carmine.

Alar expanse. $-15-17 \mathrm{~mm}$.

Habitat.-St. Jean, Maroni River, French Guiana. Wm. Schaus, collector.

Type.-Cat. No. 13559, U.S.N.M.

A very striking brilliantly colored insect.

FILINOTA PERUVIELLA, new species。

Plate 8, fig. 9.

Labial palpi light golden yellow. Face silvery white. Head yellow touched with carmine. Antennæ yellow. Thorax yellow with carmine anterior and posterior spots. Forewings light yellow with carmine and blackish brown streaks. Base of costal edge carmine; three longitudinal carmine lines on basal part of the wing; from 
basal fourth of costa to the middle of dorsum and back to the apical third of costa runs a narrow blackish brown line shaped like a V, lightly edged with carmine; across the tip of the wing runs a similar brown line, also edged with carmine, parallel with the outer leg of the $V$ and connected with it by two longitudinal, somewhat oblique carmine lines. Cilia brownish yellow. Hindwings silvery white. Abdomen light yellow. Legs yellow.

Alar expanse. $-17 \mathrm{~mm}$.

Habitat.-Peru. . Schaus collection.

Type.-Cat. No. 13560, U.S.N.M.

An equally striking species, closely allied to the type of the genus but with quite different pattern and of lighter color.

Genus PELEOPODA Zeller.

Peleopoda Zeluer, Horæ Soc. Ent. Rossicæ, vol. 13, 1877, p. 385.

Type.-Peleopoda lobitarsis Zeller.

Though Zeller's generic descriptions are totally inadequate for absolute determination, I feel reasonably assured in applying his name Peleopoda to the present genus, which has the following characters: Labial palpi rather short, hardly reaching vertex; second joint thickened with loose scales toward apex; terminal joint short, pointed. Antennæ about half the wing length, ciliated; basal joint without pecten, thickened with scales. Tongue short. Thorax and abdomen robust. Forewings elongate, two and one-half times as long as broad; slightly broadened outwardly; costa straight, a little deflected toward apex; apex bluntly pointed; termen straight, oblique; 12 veins; 7 and 8 stalked; 7 to termen; 9 and 10 connate or stalked from end of cell, closely approximated to stalk of 7 and 8 ; or 9 out of stalk of 7 and $8 ; 2$ and 3 closely approximated from end of cell; $1^{b}$ furcate at base. Hindwings broader than forewings; costa straight; termen and dorsum evenly rounded; apex bluntly pointed; 8 veins; 6 and 7 parallel; 3 and 4 stalked; 5 cubital, parallel with 4 . Posterior tibiæ and tarsal joints with heavy bunches of compressed hairs above.

\section{PELEOPODA MARONIELLA, new species,}

Plate 8, fig. 16.

Labial palpi light ochreous, shaded with dark brown exteriorly. Face reddish brown below, white just beneath vertex. Head whitish. Antennæ white above, reddish on the underside; ciliation (1). Thorax heavily scaled, white, faintly tinted with ochreous; posterior tuft tipped with reddish brown. Forewings whitish, thickly overlaid with pink, brown, and golden scales. Costal edge from base to apical fifth rosy pink, which color spreads out on the middle of the wing and is diffused as a tint over the entire tip of the wing, more 
especially on the veins. Apical fifth of costa golden yellow, edged below by a blackish brown streak. On the middle of dorsum is a large brown area and dark brown scales are sprinkled over most of the wing aggregating into short dark streaks, of which the longest is on the middle of the wing at the base, two smaller ones on the cell and still smaller and less defined ones along the apical veins. Just beyond the cell is a large diffused very pale golden blotch. Cilia whitish with dark brown streaks. Hindwings golden fuscous with dark brown veins. Abdomen dark golden brown above; genitalia and underside golden white. Hind legs heavily tufted on tibiæ and tarsal joints; pink on the inner side, dark brown exteriorly. Underside of wings golden fuscous with costa of forewings broadly rosy pink. Veins 9 and 10 of forewings stalked.

Alar expanse. $-26 \mathrm{~mm}$.

Habitat.-St. Jean, Maroni River, French Guiana. Wm. Schaus, collector.

Type.-Cat. No. 13561, U.S.N.M.

PELEOPODA NOTANDELLA, new species.

Plate 8, fig. 15 .

Labial palpi dark yellow, shaded externally with carmine. Lower face yellow, upper face white, along the eyes carmine. Antennæ reddish yellow, ciliation (1). Thorax and head white, collar touched with red. Forewings pinkish white with red golden and blackish brown ornamentation. Basal half of costal edge rosy pink; outer third dark golden yellow, which color widens out to an oval costal spot just before apex. Beyond the cell is a large ill-defined pale golden spot. Dark brown scales are sprinkled over the cell, over and around the pale golden spot and below the dark yellow apical spot; an ill-defined streak of brown scales runs from the end of the cells to termen and along the terminal edge are five small brown dots. Cilia rose. Hindwings pale brick red, cilia lighter. Abdomen pale red above, underside and genitalia golden yellow. Legs yellow-ish with heavy pale rose-colored tufts on tibiæ and tarsi. Underside of wings pale brick red. Forewings with vein 10 connate with and vein 9 out of stalk of 7 and 8 .

Alar expanse.-19-20 mm.

Habitat.-St. Jean, Maroni, French Guiana. Wm. Schaus, collector.

Type-Cat. No. 13562, U.S.N.M.

Cotype in British Museum.

PELEOPODA IRENELLA, new species.

Plate 8, fig. 17.

Labial palpi carmine red; tip of apical joint white. Face, head, and thorax white. Antennæ yellow, dotted with black above. Forewings 
white, but heavily overlaid with dark brown and saffron yellow scales. A large spot on the middle of costa and the basal half of dorsum pure white. The golden yellow consists of a broad streak along the fold, a large ill-defined spot at the end of the cell transversed by a white zigzag line, and a broad ill-defined band, running from this spot down to termen and along the termined edge around apex to costa. The space between this golden yellow edge and the central yellow spot is suffused with dark brown scales, densest toward apex; a large dark brown triangular spot occupies the space along basal third of costa across the cell to the yellow fold. Hindwings blackish brown; cilia lighter brown. Abdomen dark brown above; underside pale golden; genitalia saffron. Underside of the wings dark fuscous. Front legs thickened with tufts of carmine red, tipped with white. Hind and middle legs yellowish, shaded with brown; tarsal tufts small, whitish.

Alar expanse. $-25 \mathrm{~mm}$.

Habitat.-St. Jean, Maroni River, French Guiana. Wm. Schaus, collector.

Type.-Cat. No. 13563, U.S.N.M.

HASTA, nev genus.

Type.-Hasta argentidorsella Busck.

Labial palpi very long, recurved, overarching the thorax; second joint particularly long with basal half thin and upper half thickened with compressed scales which protrude at apex; terminal joint thin, smooth pointed, shorter than second. Antennæ simple, with pecten on basal joint. Forewings two and a half times as long as broad; costa evenly arched; apex bluntly pointed; termen sinuate below apex; anal angle pronounced; 12 veins; 7 and 8 stalked 7 to termen; 9 out of the stalk of 7 and $8 ; 2$ and 3 stalked $; 1^{b}$ furcate at base. Hindwings as broad as forewings; costa straight; apex blunt; termen and dorsum evenly rounded; 8 veins; 6 and 7 parallel; 3 and 4 connate; 5 cubital. Posterior tibiæ roughly haired.

Allied to Anchinia Hübner, but without raised scales on the forewings, and differing as well in palpal structure as in the venation and form of the forewing.

\section{HASTA ARGENTIDORSELLA, new species.}

Plate 8, fig. 3.

Labial palpi ocherous; tip of second joint brown. Face light yellow. Head dark ocherous. Thorax ocherous with a large central and posterior white patch. Forewings light yellowish brown, lightest along the costa; dorsum from base nearly to tornus silvery white, the color reaching up beyond the fold in an ill-defined triangle just beyond the middle of the wing; this dorsal white is broken by a dark brown spot, reaching from the upper dark part of the wing to the dorsal 
edge before the middle of the wing, and by a group of deep blackish brown scales at apical third. Hindwings light yellowish fuscous. Abdomen and legs ocherous.

Alar expanse.-16-18 $\mathrm{mm}$.

Habitat.-Castro, Parana, Brazil. Schaus collection.

Type.-Cat. No. 13564, U.S.N.M.

This species reminds one in form and ornamentation of the wings somewhat of certain Cerostoma species.

GONADA, new genus.

\section{Type.-Gonada falculinella Busck.}

Labial palpi recurved, reaching vertex; second joint thickened with appressed scales; terminal joint shorter than second, slim, smooth, pointed. Antennæ $\frac{4}{5}$, finely serrated and ciliated; basal joint without pecten. Tongue short. Forewings two and one-half times longer than broad, falcate; costa strongly arched; apex pointed, produced over the deeply incised termen; anal angle strongly produced; dorsum sinuous. Twelve veins; 7 and 8 stalked, both to costa; 9 separate; 10 distant; lower corner of cell, bearing 2, 3, 4, and 5, strongly produced; 3 and 4 connate. Hindwings as broad as forewings; costa straight; termen and dorsum evenly rounded; 8 veins; 6 and 7 parallel; 5 cubital, parallel with $4 ; 3$ and 4 short-stalked. Posterior tibiæ roughly haired above.

Allied to Necedes Walsingham, differing in wing form and palpi and in the connate veins 3 and 4 of the forewings.

GONADA FALCULINELLA, new species.

Plate 8, fig. 5 .

Labial palpi light yellow, with a dark brown longitudinal streak on the upper side of second joint from base to apex, continued on the anterior side of terminal joint. Face whitish, ocherous brown along the eyes. Head and thorax light ocherous. Antennæ light ocherous, dotted with dark brown above. Forewings light purplish brown with dorsal area below the fold from base to apical third of dorsum light yellow. The entire wing is sparsely and irregularly sprinkled with black atoms. Costal edge narrowly blackish brown. Cilia light brown, with tips black at tornus. Hindwings light yellowish fuscous; cilia light yellow. Abdomen light yellow. Legs whitish, forelegs blackened exteriorly. Underside of forewings brown with the dorsal yellow design of the upper side plainly discernable.

Alar expanse. $-23 \mathrm{~mm}$.

Habitat.-St. Jean, Maroni River, French Guiana. Wm. Schaus, collector.

Type.-Cat. No. 13565, U.S.N.M.

This species has a close superficial resemblance to Falculina ochricostata Zeller. 


\section{CRYPTOLECHIA ROSEOMARGINELLA, new species.}

Plate 9, fig. 37 .

Base of second joint of labial palpi blackish brown; tip and apical joint rosy white sprinkled with brown. Face, head, and thorax light ocherous. Forewing shining ocherous white with dark brown dusting, and with entire costa and terminal edge broadly rosy red. The dark brown scales are irregulary sprinkled over the wing with a first and second discal spot basely emphasized. From apical fourth of costa runs a dark brown line in an outward curve across the wing to dorsum. Cilia rosy with a faint dark marginal line. Hindwings very light lemon yellow with white cilia. Abdomen ocherous. Legs ocherous white. Venation and palpi typical of the genus.

Alar expanse. $-20 \mathrm{~mm}$.

Habitat.-St. Jean, Maroni River, French Guiana. Wm. Schaus, collector.

Type.-Cat. No. 13566, U.S.N.M.

A striking species unlike any known to the writer, but to be associated with C. canariella and C. huachuella Busck, described from Arizona.

\section{Family STENOMID无.}

STENOMA MAJOR, new species.

Plate 8, fig. 8.

Labial palpi ocherous. Antennæ ocherous fuscous, ciliated (1). Face whitish. Head and thorax light ocherous. Forewings elongate with costa evenly arched, reaching its highest point beyond the middle, thence abruptly declined to the sharply pointed, slightly protruded apex; termen oblique; dorsum straight; light ocherous with the entire edge narrowly dark ocherous brown and with three nearly equidistant and parallel, transverse, oblique ocherous brown streaks across the wing; the first of these streaks begins at basal third of costa and reaches to the fold, which is itself ocherous brown; the second begins before the middle of costa and reaches to tornus; the third begins beyond the middle of costa and reaches termen. Hindwings light yellow. Abdomen and legs yellow; tarsal joints not tufted as in the allied species.

Alar expanse. $-50-60 \mathrm{~mm}$.

Habitat.-Callao, Peru. Mrs. M. J. Pusey, collector.

Type. Cat. No. 13567, U.S.N.M.

Cotype in British Museum.

The largest species known in the genus, closely related to Stenoma loxotoma Busck and S. fraternella Busck, but lighter in color, with much more pointed wings and with the three oblique streaks somewhat differently placed. 
STENOMA IO, new species.

Plate 8, fig. 2.

Second joint of labial palpi carmine red; terminal joint dark brown with yellow tip, short. Antennæ reddish ochreous shaded with black above. Face light carmine. Head and collar deep brown. Thorax light brown with darker purple reflections. Forewings broad, not quite two and one-half times as long as wide; costa gently arched from base to apex; apex sharply pointed, somewhat produced; termen slightly sinuate; tornus produced, evenly rounded; dorsum straight from tornus to basal third, thence abruptly inclined toward base; color chestnut brown, overlaid on the basal two-thirds with a darker purple tint; the two shades rather sharply defined by a line from about the middle of costa to the beginning of the dorsal cilia. On the end of the cell lies a large irregularly triangular ocellate spot, deep velvety brown surrounded by a thin line of light yellow; obliquely below and before lies a similar smaller oblong spot on the fold and on the cell is a small aggregation of dirty yellow scales. Cilia short, dirty yellow with a black line parallel with the edge of the wing. Hindwings bright brick red, cilia yellowish. Abdomen and legs deep brick red. Underside of body and of both wings bright brick red.

Alar expanse. $-46 \mathrm{~mm}$.

Habitat.-St. Jean, Maroni River, French Guiana. Wm. Schaus, collector.

Type.-Cat. No. 13568, U.S.N.M.

A very striking species unlike any described Stenoma, but most nearly allied to the foregoing group.

STENOMA ACRONITIS, new species.

Plate 8, fig. 19.

Second joint of labial palpi deep black with white tip; terminal joint white, sprinkled with black. Antennæ yellowish fuscous. Face dirty white, sprinkled with black. Head pure white. Thorax white, sprinkled with gray. Forewings short and broad with tufts of raised scales; costa straight; apex rounded; termen oblique; color chalky white, sparsely speckled with brown atoms and with blackish brown design; from basal fourth of costa runs a blackish brown streak in over the cell, outwardly, through the end of the cell, toward the middle of termen, but dividing shortly before the edge into two branches, of which one curves upward to a black, triangular, costal spot at apical fourth, while the other curves downwards and ends on the dorsal edge before tornus; the streak is not continuous, but is interrupted and enlarged at its entrance into the cell and at the end of the cell; between its base and the aforementioned large 
costal spot is a small black costal dash; around the edge of the wing is a thin black line from the large costal spot to tornus, on which a series of small black dots, one at the terminus of each vein. Cilia dirty white. Hindwings dark, blackish fuscous. Abdomen blackish fuscous with dirty white anal tuft. Legs dark fuscous; tarsi black with white annulations.

Alar expanse. $-34-40 \mathrm{~mm}$.

Habitat.-St. Jean, Maroni River, French Guiana. Wm. Schaus, collector. British Guiana. C. W. Bebee, collector.

Type.-Cat. No. 13569, U.S.N.M.

Cotype in British Museum.

STENOMA MENDORON, new species.

Plate 8, fig. 20.

Labial palpi dirty white, sprinkled with brown and with base of both joints black. Antennæ ochreous annulated with black above. Face and head white. Collar and thorax white sprinkled with brown, thorax with light-brown posterior tufts. Forewings rather short with straight costa, rounded apex, and termen oblique; with tufts of raised scales; ground color white sprinkled liberally with light brown; three equidistant small, black costal spots, the outer two most prominent, all edged with brown; at the end of the cell a short deep black transverse dash preceded by a brown spot; from this a perpendicular brown streak down to dorsal edge just before tornus; at apical fifth a premarginal line of brown spots parallel with termen. Cilia white with equidistant brown tufts appearing as a marginal line of brown dots. Hindwings triangular dark brown; cilia whitish with a brown marginal line. Abdomen dark fuscous with underside and anal tuft ochreous. Forelegs of the male deep brown with black, white annulated tarsi; hindlegs brown with darker tarsi, annulated with white. The females have somewhat lighter hindwings and abdomen and especially lighter more ocherous legs.

Alar expanse. $-24-26 \mathrm{~mm}$.

Habitat.-St. Jean, Maroni River, French Guiana. Wm. Schaus, collector.

Type.-Cat. No. 13570 , U.S.N.M.

Cotype in British Museum.

Closely related to Stenoma acronitis, but smaller and with a more mottled design.

STENOMA NESTES, new species.

Plate 8, fig. 18 .

Labial palpi dirty white, liberally sprinkled with dark brown; basal half of second joint black above. Face dirty white. Antennæ yellowish with brown annulations. Head and throax white strongly 
suffused with brown. Wings of the form as in the two preceding species. Forewings with tuft of raised scales, reddish white, strongly suffused with brown scales; three blackish brown equidistant costal spots, the basal one the smallest, the outer most prominent, large triangular; a short deep black transverse dash at the end of the cell, preceded by a pure white spot, before which a thin longitudinal deep black line across the cell to base of vein 11; a large ill-defined cloud of dark brown scales above tornus; cilia reddish white with small dark brown dots around the margin from apical fifth of costa to tornus. Hindwing dark brown, cilia lighter brow. with a dark basal line. Abdomen dark fuscous with ochreous tip and underside. Legs ocherous white mottled with brown; tarsi dark brown with ochreous annulations.

Alar expanse. $-25-28 \mathrm{~mm}$.

Habitat.-St. Jean, Maroni River, French Guiana. Wm. Schaus, collector.

\section{Type-Cat. No. 13571, U.S.N.M.}

Closely allied to the two foregoing species, intermediate in size, darker than both, more reddish in color and easily distinguished by the thin longitudinal black line on the cell and by the dark spot near tornus.

STENOMA TRASTICES, new species.

Plate 9, fig. 34.

Second joint of labial palpi light brown with white tip; terminal joint light brown with two darker brown annulations. Face white. Antennæ dark brown with lighter basal joint. Head light ocherous. Collar rich brown. Thorax speckled with white and dark brown scales. Forewings with the bluish white ground color heavily obscured by dark brown and black scales, especially on dorsal half. At basal fourth is a dark brown costal spot; just beyond the middle of costa is a small blackish brown zigzag streak, and at apical fourth is a large dark brown costal blotch which extends over most of the tip of the wing with exception of an oblong yellow dash before apex and of the extreme edge which is whitish. Cilia dark brown. Hindwings dark brown. Abdomen dark brown above, ocherous underneath. Legs light brown with dark brown tarsi.

Alar expanse. $-16-22 \mathrm{~mm}$.

Habitat.-Cayenne and St. Jean, Maroni River, French Guiana. Wm. Schaus, collector.

Type.-Cat. No. 13572 , U.S.N.M.

Cotype in British Museum.

STENOMA APICALIS, new species.

Plate 8, fig. 13.

Labial palpi reddish brown. Antennæ dark fuscous. Face and head dark brown. Collar and thorax golden brown. Forewings in 
shape like the three preceding species with scale tufts; base light golden ocherous with a thin dark brown costal margin and a broader dark dorsal margin; the central two-thirds of the wing dark brown mixed with bluish white scales, the three upper ones of which are golden ocherous, while the two smaller lower ones have the same color as the surrounding parts; all the tufts, but especially the lower ones, are followed by black scales. The central dark color stops on the edges at apical fourth, but projects on the middle out into a sharp tongue which reaches the terminal edge and separates two large light golden brown round areas, the upper including apex the lower surrounding tornus; these light terminal areas are sparsely edged with white scales. Cilia dark brown, darkest at apex. Hindwings dark blackish brown. Abdomen dark brown with ocherous anal tuft. Legs dark brown; tarsi with ocherous annulation.

Alar expanse. $-25 \mathrm{~mm}$.

Habitat.-St. Jean, Maroni River, French Guiana. Wm. Schaus, collector.

Type.-Cat. No. 13573, U.S.N.M.

Related to the foregoing species, but of more complex design and color, easily recognized by the apical golden brown areas.

STENOMA LACTIS, new species.

Plate 8, fig. 6 .

Labial palpi creamy white with base of second joint and tip of terminal joint black. Antennæ dark fuscous. Face and head white. Thorax white tinted with yellow and with an ocherous posterior tuft. Forewings short and broad of the same shape as in Stenoma mendoron; basal third ocherous white, terminal two-thirds dark fuscous, the limits of the two colors sharply drawn by a slightly outwardly curved pure white line from basal fourth of costa to shortly before the middle of dorsum. In the dark part of the wing are several small scale tufts mixed with black scales; at the end of the cell is a small ocherous tuft followed by black. Cilia fuscous. Hindwings triangular, dark fuscous. Abdomen dark fuscous with ocherous underside and anal tuft. Legs ocherous, mottled with fuscous; tarsi darker with ochreous annulations.

Alar expanse. - $19-21 \mathrm{~mm}$.

Habitat.-St. Jean, Maroni River, French Griana. Wm. Schaus, collector.

Type. Cat. No. 13574, U.S.N.M.

Cotype in British Museum.

Allied to the foregoing species; easily recognized by the sharply contrasting basal and apical parts of the forewings. 
STENOMA FASCIATUM, new species.

Plate 8, fig. 10.

Labial palpi light ocherous, second joint shaded with black exteriorly, termined joint with extreme base black. Antennæ yellowish fuscous. Face light ocherous. Head and thorax ocherous fuscous. Forewings elongate oval; apex not indicated; termen evenly rounded; light grayish ocherous with a broad blackish brown oblique fascial this begins on costa from basal fourth to the middle of costa and reaches to the middle of dorsum; the edges are not even but reasonably parallel and sharply defined against the lighter basal and apical parts of the wing; at apical third is an indistinct and ill-defined dark fuscous cloud parallel with the fascia and mainly noticeable by its outer edge, which appears as a dark, thin, undulating line from a small costal spot to tornus. Hindwings dark fuscous. Abdomen dark fuscous above with ocherous underside and anal tuft; legs ochreous.

Alar expanse. - 21-24 mm.

Habitat.-Cayenne, French Guiana. Wm. Schaus, collector. British Guiana. C. W. Bebee, collector.

Type.-Cat. No. 13575, U.S.N.M.

Easily recognized by the rounded apex and the bold design of the forewings.

\section{STENOMA VENATUM, new species.}

Plate 8, fig. 14 .

Second joint of labial palpi ocherous shaded with black; terminal joint black with ocherous tip. Antennæ blackish above, ocherous underneath. Face light ocherous. Head blackish brown. Thorax light ocherous with two small black lateral dots and with black posterior tuft. Forewings light grayish ocherous, whitish above the cell, with all veins sharply marked by black lines; terminal edge black; two black dots near base within the dorsal edge. Cilia ocherous fuscous. Hindwings dark fuscous with ocherous cilia. Abdomen dark fuscous above with whitish ocherous underside. Forelegs blackish brown with narrow ocherous annulation at the joints; hindlegs ocherous.

Alar expanse. $-26 \mathrm{~mm}$.

Habitat.-St. Jean, Maroni River, French Guiana. Wm. Schaus, collector.

Type.-Cat. No. 13576, U.S.N.M.

A striking species closely allied to Stenoma renselariana Cramer, disjecta Zeller and loxogrammos Zeller, but without any large black dorsal areas, as found in those species. 
STENOMA GUNNI, new species.

Plate 8, fig. 4 .

Second joint of labial palpi ocherous below, white above, and blackish brown at base and apex; terminal joint blackish brown, with a white annulation just before apex. Face whitish, head dark brown. Thorax dark green, strongly metallic, with posterior tuft of same color. Basal third of forewings strongly metallic, iridescent, dark purplish brown with green metallic dorsal edge, separated from the purplish part by a thin white line; this dark base is sharply defined against the white ground color of the middle part of the wing, and reaches to basal fourth on costa and to near the middle of dorsum; the following white part is mottled by soft gray spots of which a large quadrangular one lies on the dorsal edge and reaches nearly to the middle of the wing; another large gray spot forms an ill-defined fascia from costa to dorsum and is followed by a narrow white line across the wing; the apical part outside of this white line is light golden brown. Cilia gray. Hindwings with strongly developed costal area ciliated to the base, much broader than the forewings; dark greenish brown, with whitish cilia. Abdomen dark brown with ocherous anal tuft. Legs whitish gray with smoky tarsi.

Alar expanse. - 24-25 mm.

Habitat.-St. Laurent, Maroni River, French Guiana. Wm.Schaus, collector.

Type.-Cat. No. 13577, U.S.N.M.

This species would have been determined by Zeller as a typical Antrotricha. It belongs to the group herilis Felder, reciprocella Walker, and ribbei Zeller, from all of which it differs by the deep metallic green dorsal base and by the golden tips of the forewings. I am unable to maintain the genus Antrotricha Zeller as distinct from Stenoma Zeller.

STENOMA COMMA, new species.

Plate 8, fig. 11.

Labial palpi light ocherous. Face and head light ocherous. Thorax darker reddish ocherous. Forewings white, the basal half heavily overlaid with light ocherous brown scales, such as are also sprinkled over the apical part of the wing; at the end of the cell is a short transverse dark-brown streak; from apical fourth of costa runs an outwardly curved brown line down to tornus; apical and terminal edge blackish brown; cilia white. Hindwings ocherous white with light fuscous tip and with a very conspicuous black dash on vein $1^{\text {b }}$; cilia white. Abdomen and legs light ocherous.

Alar expanse.-14-15 $\mathrm{mm}$.

Habitat.-Cayenne, French Guiana, and Cuba. Wm. Schaus, collector.

Type.-Cat. No. 13578, U.S.N.M. 
A dainty little light species at once distinguished by the black contrasting dash on anal part of the hindwings.

STENOMA SPERATUM, new species.

Plate 9, fig. 31.

Labial palpi whitish on the inner side, reddish brown exteriorly. Lower part of face silvery white; upper part and the base of the antennæ rich reddish brown. Head dark gray. Thorax brown. Forewings dull brown with a large central oval spot on the disk light leaf-green, slightly edged with yellow and with a dark-brown margin; a smaller round green spot lies on the dorsal edge just below the end of the Aarge discal spot. Cilia dark brown. Hindwings light ocherous brown. Abdomen and legs ocherous brown.

Alar expanse. $-20 \mathrm{~mm}$.

Habitat.-Cayenne, French Guiana. Wm. Schaus, collector.

Type. Cat. No. 13579, U.S.N.M.

STENOMA SALOME, new species.

Plate 9, fig. 39.

Labial palpi and face light ocherous. Head and thorax light drab. Forewings light-drab colored, with reddish-brown ornamentation; near base is a thin, outwardly bent, brown zigzag line across the wing, followed by a small metallic blue dot on the fold and a small dark-brown dot on the cell. Across the middle of the wing runs a brown line, obliquely from before the middle of costa to beyond the middle of dorsum; this is followed by a light ocherous spot, edged with brown at the end of the cell; on apical third of costa is a small brown, triangular spot, continued faintly in a very thin, notched, outwardly bent brown line across the wing; apical half of costa, entire terminal edge, and apical half of dorsum reddish brown with a marginal series of darker brown dots within; cilia whitish. Hindwings light ocherous fuscous with whitish cilia. Abdomen and legs ocherous fuscous.

Alar expanse. $-22-23 \mathrm{~mm}$.

Habitat.-Castro, Parana, Brazil. Schaus collection. Type.-Cat. No. 13580, U.S.N.M.

STENOMA INSCITUM, new species.

Plate 9, fig. 33.

Labial palpi whitish ocherous, shaded with dark brown exteriorly. Face and head ocherous white. Thorax fuscous. Patagia white with purplish-brown base. Collar purplish brown. Forewings whitish fuscous, the ground color being white but strongly and unevenly overlaid with dark fuscous except for a large oblong pure white costal spot reaching from basal fourth to apical fourth. At the end of the cell is a dimly indicated darker fuscous spot from which a faint dark 
- fuscous irregular line runs to dorsal edge near base. Extreme tip of wing dark bronzy brown. Cilia white. Hindwings dark fuscous with whitish cilia. Abdomen dark fuscous above; underside and legs ocherous.

Alar expanse.-19-22 mm.

Habitat.-St.Laurent, Maroni River, French Guiana. Wm. Schaus, collector.

Type.-Cat. No. 13581, U.S.N.M.

STENOMA THORISTES, new species.

Plate 9, fig. 22.

Labial palpi whitish ocherous, shaded with brown exteriorly. Face light ocherous. Antennæ brown. Head drab. Thorax rich brown anteriorly, light drab posteriorly. Forewings light drab with a purple sheen and with deer-brown markings; basal third is mottled with brown scales except along costa in ill-defined and somewhat variable pattern; central part of the wing is unmottled, except for a small brown costal spot; on the apical third is a broad ill-defined brown fascia across the wing, margined externally by an outwardly -curved line of small black dots; around the terminal edge and reaching round both on costa and dorsum is a marginal row of more prominent small black dots. Cilia drab. Hindwings light dirty strawyellow with a marginal row of small, black, nearly confluent dots. Abdomen ocherous fuscous above; underside light ocherous; anal tuft deep ocherous. Legs ocherous; hind legs with first tarsal joint strongly tufted as in S. elegans Zeller, S. loxotoma Busck, and S. fraternella Busck, with which species it otherwise has no close affinity. Alar expanse.-29-34 mm.

Habitat.-St. Jean, Maroni River, French Guiana. Wm. Schaus, collector.

Type.-Cat. No. 13582, U.S.N.M.

Cotype in British Museum.

Allied to Stenoma immundum Zeller and S. sororium Zeller, differing in the brown markings, not present in those species.

STENOMA MARONI, new species.

Plate 9, fig. 23.

Second joint of labial palpi dark purplish brown; tip and apical joint whitish. Face ocherous white. Head and thorax dark brown. Forewings light brown with a broad dark reddish brown transverse band occupying the larger middle part. This dark brown shade is well defined and extends from base to apical fourth of dorsum obliquely across the wing to outer half of costa with tolerably parallel edges; at basal third is a light ocherous gray slightly dark ocellated dorsal spot. From the outer edge of the dark shade runs an undulat- 
ing dark brown line down to dorsum just before tornus. Along the terminal edge is a faint row of dark brown dots. Cilia light brown. Hindwings dark brownish fuscous with a light ocherous marginal line before the cilia. Abdomen dark brown above; underside and legs light ocherous.

Alar expanse. $-24-28 \mathrm{~mm}$.

Habitat.-St. Jean, Maroni River, French Guiana. Wm. Schaus, collector.

Type.-Cat. No. 13583, U.S.N.M.

Cotype in British Museum.

STENOMA VANIS, new species.

Plate 9, fig. 32 .

Labial palpi ocherous, shaded with dark brown exteriorly. Face ocherous. Head and thorax dark purplish brown; thorax with bright reddish brown posterior tuft. Forewings light brown with dark brown and reddish brown markings as follows: From inner angle of dorsum runs a broad rich reddish brown shade to the end of the cell; from middle of costa runs a blackish brown shade outwardly toward but not reaching the middle of termen; costal edge outside of this shade broadly blackish brown; doisal edge from base to beyond middle broadly blackish or purplish brown. Terminal edge broadly reddish brown. Cilia dark brown with light ocherous base. Hindwings dark brownish fuscous with ocherous cilia. Abdomen dark brown above, underside ocherous. Legs ocherous; forelegs shaded with dark brown anteriorly.

Alar expanse. $-25-30 \mathrm{~mm}$.

Habitat.-St. Jean, Maroni River, French Guiana. Wm. Schaus, collector.

Type.-Cat. No. 13584, U.S.N.M.

Cotype in British Museum.

STENOMA ADDON, new species.

Plate 9, fig. 36.

Labial palpi white, second joint tinted with ocherous exteriorly and with a black spot on theinner (upper) side at base. Face white, brownish along the eyes. Head and thorax gray. Forewings with the white ground color suffused with light soft gray, somewhat darker on dorsal than on costal half. Two dark grayish brown zigzag lines across the wing very faint on the costal side, stronger and emphasized by heavy washed, dark shades externally on the dorsal side; the one begins at basal third of costa and runs to middle of dorsum, the other begins on the middle of costa and runs to apical fourth of dorsum; yet farther out on the wing is a thin evenly outwardly curved line across the 
wing. Cilia white. Hindwings dark fuscous with white cilia. Abdomen dark fuscous above, underside whitish, anal tuft ocherous. Legs ocherous white.

Alar expanse. $-25 \mathrm{~mm}$.

Habitat.--Rockstone, Essequebo River, British Guiana; Cayenne and St. Jean, Maroni River, French Guiana. Wm. Schaus, collector.

Type.-Cat No. 13585, U.S.N.M.

Cotype in British Museum.

Of the group represented by $S$. crocuta, genetta, and fraterna Felder; larger than either of these and differing in the heavy, dark, washed out bases of the transverse faciæ. It comes still nearer to the larger S. binubila Zeller, which is even more like the following species, but the size alone sufficiently separates both species.

STENOMA PHGEBE, new species.

Plate 9, fig. 42 .

This may best be described by comparison with the foregoing species, to which it comes very close. The upper, costal, half of the forewings is nearly pure white instead of merely lighter gray as in $S$. addon, and only the two outer fasciæ can be traced in this part of the wing. The first, basal, fascia is represented by the dorsal spot only, broadly washed out and somewhat nearer the base than in $S$. addon. The series of small black marginal dots is rather more distinct than in the former species. The hindwings whitish, light fuscous toward tip, are strikingly lighter than the hindwings of S. addon.

Alar expanse. $-21-22 \mathrm{~mm}$.

Habitat.-St. Jean, Maroni River, French Guiana. Wm. Schaus, collector.

Type.-Cat. No. 13586 , U.S.N.M.

Evidently very close to $I$. binubila Zeller and nearly identical in pattern, but the much smaller size and the different localities of the two species make the distinctness of the present species reasonably certain.

STENOMA SIMILIS, new species.

Plate 9, fig. 43.

Closely allied to Stenoma phobe, but smaller and with a more sharply defined pattern. Labial palpi whitish shaded with fuscous. Face silvery white. Head and thorax dark gray. Forewings with costal half light, nearly white; dorsal half dark fuscous; three nearly equidistant transverse oblique streaks; the basal one stopping at a small black dot on the middle of the cell; the second one continued somewhat farther up and including a small black dot at the end of the cell; the third reaching across to the costal edge; the bases of the two first streaks are strongly washed into large blackish dorsal shades, reach- 
ing nearly to the following streak. Hindwings whitish fuscous. Abdomen dark fuscous above; underside and legs whitish. Alar expanse. $-17-19 \mathrm{~mm}$.

Habitat.-St. Jean, Maroni River, French Guiana. Wm. Schaus, collector.

Type.-Cat. No. 13588, U.S.N.M.

Cotype in British Museum.

STENOMA DEMAS, new species.

Plate 9, fig. 40.

Second joint of labial palpi white, shaded externally with blackish fuscous; terminal joint white, with base and an annulation near the tip black. Face silvery white. Head and thorax ocherous. Forewings white, with a large black basal spot on dorsum and a bold oblique black fascia across the wing beyond the cell; this fascia is evenly concave on the inner side, irregularly bent on the outer side, and broader at the dorsal end than at costa. Extreme apical edge black. Cilia white. Hindwings white. Abdomen light ocherous fuscous above; legs and underside white.

Alar expanse. $-14 \mathrm{~mm}$.

Habitat.-St. Jean, Maroni River, French Guiana. Wm. Schaus, collector.

Type.-Cat. No. 13588, U.S.N.M.

While this species is clearly nearly related to and very similar to the foregoing group of species, it is at once distinguished by its small size and its striking clear-cut wing pattern.

STENOMA HAMON, new species.

Plate 9, fig. 41.

Labial palpi blackish brown, with the tip of second joint and the base of terminal joint shaded with white. Face white. Head and thorax dark fuscous. Forewings white, sprinkled with brown atoms, and with three oblique irregular blackish brown lines across the wing; the first of these is nearly straight, only slightly zigzag, and runs from basal fourth of costa to shortly before middle of dorsum; the second line is much more irregular and runs reasonably parallel with the first just outside the cell; the third line is evenly convex, with a sharp indentation at costal third. Around the entire edge is a prominent series of small equidistant dark brown dots. Hindwings dark fuscous. Abdomen dark fuscous above; underside light ocherous. Legs ocherous; tarsi annulated with black.

Alar expanse. $-22-23 \mathrm{~mm}$.

Habitat.-St. Jean. Maroni River and Cayenne, French Guiana, Wm. Schaus, collector.

Type-Cat. No. 13589, U.S.N.M. 


\section{Genus GONIOTERMA Walsingham.}

Gonioterma Walsingham, Proc. Zool. Soc. Lond., 1897, p. 101.

\section{Type.-Goniterma burmanniana Cramer.}

This is one of the few genera, erected in this family, which seems tenable, and it undoubtedly represents a natural group of Stenomid moths, characterized by the square forewings and the black costal spots; but it should be observed that even this group is none too sharply defined in nature and that many species come uncomfortably close to it in appearance, without having vein 8 of the forewings to termen below apex, which character I consider the one essential in the differentiation from Stenoma Zeller. Such species would fall in Walsingham's genus Anadasmus, which I can not maintain as distinct from Stenoma Zeller, on account of the perfecly gradual transition between the extremes of wingform.

GONIOTERMA ROSA, new species.

Plate 9, fig. 28.

Labial palpi rosy, shaded with black exteriorly. Face and head light ocherous. Thorax rosy ocherous. Forewings light rosy ocherous with two conspicuous dark brown, costal spots, one just beyond the middle of the wing, one at apical fifth; from basal third of costa runs a thin light brown straight line obliquely across the wing to the middle of dorsum; on the end of the cell is a very faint, transverse line of dark brown scales; along the terminal edge is a series of short black marginal streaks; cilia dark reddish fuscous. Hindwings light reddish yellow; cilia light straw-colored. Abdomen and legs light ocherous.

Alar expanse. $-23 \mathrm{~mm}$.

Mabitat.-St. Jean, Maroni River, French Guiana. Wm. Schaus, collector.

Type-Cat. No. 13590, U.S.N.M.

Of the general shape and ornamentation of Gonioterma burmanniana Cramer and Gonioterma isabella Felder; smaller than both these species and easily recognized by its quite different color.

GONIOTERMA ANNA, new species.

Plate 9, fig. 27.

Labial palpi white, second joint shaded exteriorly with dark brown. Face and head ocherous white. Forewings very light rosy drab with three triangular, equidistant, blackish brown, costal spots, the two outer ones large and very prominent, the basal one at basal third of costa smaller; on the end of the cell is a small transverse dark brown spot; from the tip of the outer costal spot runs an outwardly curved 
row of small equidistant dark brown dots across the wing to dorsum; extreme terminal edge deep black; cilia dark brown. Hindwings whitish with yellow tips, cilia yellowish fuscous. Abdomen and legs light ocherous.

Alar expanse.-18-21 mm.

Habitat.-Geldersland, Surinam River, Dutch Guiana. Wm. Schaus, collector.

\section{Type.-Cat. No. 13591, U.S.N.M.}

Quite close to the foregoing species, from which it is distinguished by the additional costal spot and the absence of an oblique line across the forewings, as well as by the different color and smaller size.

\section{GONIOTERMA STELLA, new species.}

Plate 9, fig. 29.

Labial palpi whitish with base and exterior side of second joint dark brown. Face and head light drab. Thorax light bluish drab, sprinkled with black atoms. Forewings light bluish drab, sprinkled with black scales; two dark brown costal spots, one on the middle of costa, one at apical sixth; a similar spot is found on the cell at basal third; from the tip of the outer costal spot runs a faint, outwardly curved, row of small black dots just within terminal edge to dorsum, and on the extreme terminal edge is a more pronounced, marginal series of short, blackish brown streaks; the outer third of the wing has a slightly lighter ground color than the base; cilia bluish, darker near apex, nearly white at tornus. Hindwings dark ocherous fuscous; cilia whitish. Abdomen and legs dark fuscous.

Alar expanse. $-26-28 \mathrm{~mm}$.

Habitat.-St. Jean, Maroni River, French Guiana. Wm. Schaus, collector.

Type.-Cat. No. 13592, U.S.N.M.

Cotype in British Museum.

Larger than the two foregoing species; distinguished by its bluish color and the dark discal spot.

GONIOTERMA INGA, new species.

Plate 9, fig. 30.

Labial palpi bluish white with base and outer side of second joint dark brown. Face ocherous white. Head bluish. Thorax light brown with bluish sheen. Forewings light bluish drab, darker in shade than in $G$. stella; two deep black costal spots, one on the middle, the other at apical fifth; extreme costal edge rust-red, the color of the underside; a faint outwardly curved row of small black dots from outer costal spot to dorsum, parallel with the terminal edge; a similar row on the terminal edge; cilia reddish. Hindwings 
light yellow. Abdomen ocherous fuscous above, underside whitish, anal tuft ocherous. Legs ocherous white with darker ocherous tarsi. Alar expanse. $-22 \mathrm{~mm}$.

Habitat.-St. Jean, Maroni River, French Guiana. Wm. Schaus, collector.

Type.-Cat. No. 13594, U.S.N.M.

Closely related to and very similar to the foregoing species, especially G. rosa, but distinguished from all of them by the slightly produced apex and the sinuate termen below apex.

\section{GONIOTERIMA EMMA, new species.}

Plate 9, fig. 24.

Labial palpi light brown, darker brown at apex and on exterior side of second joint. Face ocherous. Head light brown. Thorax and forewings light deer-brown with three dark brown, not very conspicuous, triangular, nearly equidistant costal spots, one at basal third, one on the middle of costa, and one at apical fourth; from the latter runs an outwardly curved row of minute dots to dorsum. Cilia dark brown. Hindwings dark brownish fuscous. Both fore and hind wings with a strong sheen. Abdomen dark brown above, light ocherous on the underside. Legs ocherous with darker tarsi.

Alar expanse. $-26-28 \mathrm{~mm}$.

Habitat.-St. Jean, Maroni River, French Guiana. Wm. Schaus, collector.

\section{Type.-Cat. No. 13594, U.S.N.M.}

Easily distinguished from other species in this genus by its darker color, especially of the hindwings.

\section{GONIOTERIMA VITA, new species.}

Plate 9, fig. 26.

Labial palpi ocherous white, shaded with brown exteriorly. Face and head ocherous white. Thorax light ocherous. Forewings light straw yellow, with a large brown shade resting on the dorsal edge and covering most of the wing; the brown shades gradually into the yellow and leaves base, costal, and terminal edge pure yellow; on the costal edge are two very small dark brown dots, one on the middle and one at apical sixth. Cilia dark ocherous. Hindwing light straw yellow. Abdomen and legs ocherous.

Alar expanse. - 24-25 mm.

Habitat.-St. Jean, Maroni River, French Guiana. Wm. Schaus, collector.

Type.-Cat. No. 13595, U.S.N.M.

Not closely similar, but clearly allied to the other species described in this genus. 


\section{Family OLETHREUTIDA.}

OLETHREUTES GERDA, new species.

Plate 9, fig. 21.

Labial palpi dark brown, ocherous on their inner side. Face and head light brown. Thorax dark purplish brown. Forewings deep purplish brown with a large golden yellow terminal patch; basal half nearly black; costal edge and apical part rich brown without the purple tint, which is most prominent on the middle of the wing; along the costal edge is a series of short outwardly directed bluish metallic streaks intervened by small black dots; at the upper end of the cell is a fan-shaped group of thin black lines; in the yellow terminal patch, which is slightly striated transversely with black, is a row of these black dots, followed by a perpendicular bluish metallic streak before the black cilia. Hindwings deep blackish brown. Abdomen blackish brown above, lighter brown on the underside. Legs dark brown. Alar expanse. $-24-28 \mathrm{~mm}$.

Habitat.-St. Jean, Maroni River, French Guiana. Wm. Schaus, collector.

Type.-Cat. No. 13596, U.S.N.M.

Cotype in British Museum.

A large species distinguished by its wing form and the very dark hindwings.

\section{Family TORTRICIDE.}

\section{TORTRIX AURIFERANA, new species.}

Plate 9, fig. 38.

Labial palpi dark ocherous. Antennal strongly biciliate. Face and head dark brown. Thorax golden yellow. Forewings light shining golden yellow with ocherous brown ornamentation, consisting of a broad line from base along basal half of costal edge, thence across the wing obliquely to dorsal edge just before tornus, and thence upward across the wing parallel with terminal edge to costa just before apex. Near base of dorsal edge is a small thin brown line directed toward the middle of the wing. Cilia golden. Hindwing golden white. Abdomen and legs ocherous.

Alar expanse.-14-15 $\mathrm{mm}$.

Habitat.-Castro, Parana, Brazil. Schaus collection.

Type.-Cat. No. 13597, U.S.N.M.

Cotype in British Museum.

Superficially very similar to the common North American Epagoge sulphuriana Clemens, but, unlike this species, apparently constant in ornamentation. 
TORTRIX PARANA, new species.

Labial palpi brown, shaded with purple and black. Face, head, and thorax dark golden brown. Forewings dark golden yellow with dark reddish brown and black markings; from middle of costa runs a straight-edged narrow dark brown band obliquely across the wing to tornus; from apical fourth of costa runs a similar parallel band across the wing to termen; on the middle of the cell is a large ill-defined dark brown spot dusted with black scales; costal edge mottled with small black dots. Cilia light golden. Hindwings light silvery fuscous. Cilia white. Abdomen and hindlegs dark ocherous; forelegs blackish brown.

Alar expanse.-13-14 mm.

Habitat.-Castro, Parana, Brazil. Schaus collection.

Type.-Cat. No. 13598, U.S.N.M.

Cotype in British Museum.

Nearly related to the foregoing species; differing in pattern and in the dark golden color of the forewings.

\section{Family HEMEROPHILID $Æ$.}

ORDUPIA, new genus.

Type.-Ordupia friserella Busck.

Labial palpi curved, upturned, reaching vertex; second joint thickened with smoothly appressed scales; third joint shorter than second, smooth, bluntly pointed. Antennæ short, less than half the winglength; thick smooth above, below with one row of thick, closely set, short-haired lamellæ, which are twice as long as the thickness of the base. Head smooth. Forewings with straight edges, apex bluntly pointed, termen oblique, tornus pronounced; 12 veins, all separate; 2 from before the end of the cell, 3-9 from end of cell; 8 to termen; $1^{\mathrm{b}}$ furcate at base. Hindwings broader than the forewings, triangular with straight costa and nearly straight termen; 8 veins; 3 and 4 stalked; 5, 6, and 7 parallel. Posterior tibiæ with smoothly appressed long hairs above.

A peculiar noctuid-like form allied to Hemerophila Hübner, which genus may be a development from Ardrupia. The very peculiar onesided antennæ and the course of vein 8 in the forewing as well as the very different general habitus easily distinguish the present genus.

Named in fond memory of my indebtedness for my early training in Ordrup College, Denmark, under that eminent and beloved teacher, Prof. H. C. Frederiksen.

ORDRUPIA FRISERELLA, new species.

Plate 9, fig. 25.

Labial palpi brownish ocherous. Face whitish ocherous. Antennæ ocherous. Head and thorax light brownish ocherous with a blackish 
sheen. Forewings light ocherous brown overlaid with darker brown; on the middle of the wing is a broad transverse shade of dark brown, poorly defined from the lighter basal and apical parts; at the end of the cell is a small round black dot; a similar dot but much fainter is found on the middle of the cell and a third, also faint, on the fold. Cilia dark brown. Hindwings light ocherous brown; cilia whitish. Abdomen whitish ocherous on first two segments; posteriorly deep mahogany brown above and bright reddish ocherous below; anal tuft ocherous. Legs whitish ocherous.

Alar expanse. $-29-36 \mathrm{~mm}$.

Habitat.-St. Jean, Maroni River, French Guiana.

Type.-Cat. No. 13599, U.S.N.M.

Cotype in British Museum.

This species is easily mistaken for a noctuid on account of its size and robustness as well as its color and wing-form.

\section{Family TINEIDÆE.}

\section{TINEA BOLIVIANA, new species.}

Labial palpi saffron yellow with black bristles. Face and head saffron yellow mixed with dark brown. Thorax dark brown. Forewings unicolored dark slaty brown, shining, with extreme costal and dorsal edge and tufts in the cilia saffron yellow. Hindwings dark slaty brown with dorsal cilia saffron yellow. Abdomen saffron yellow. Legs yellow, shaded with dark brown. Venation typical, 7 and 8 in forewings stalked to costa; all veins separate in hindwings. Alar expanse. $-19-20 \mathrm{~mm}$.

Habitat.-Bolivia. Schaus collection.

Type.-Cat. No. 13600, U.S.N.M.

Cotype in British Museum.

A typical species of the unicolored group of the genus easily recognized by the saffron yellow edges and abdomen.

\section{PLUMANA, new genus.}

Type.-Plumana piperatella Busck.

Male.-Labial palpi short porrected, somewhat rough-scaled. Tongue obsolete. Antennæ biciliate throughout (2). Head smooth, forewing elongate about three times longer than broad; costa straight gently arched toward the bluntly pointed apex; termen oblique; tornus well developed; 11 veins; vein 6 absent; 7 and 8 long stalked; 7 to costa; $1^{\text {b }}$ furcate at base. Hingwings broader than forewings, triangular; 7 veins; 4 absent; all separate and nearly parallel; 5 cubital. Legs smooth.

Female.-Presumably apterous. 
Allied to Fumea Hubner, though of quite different general habitus; differing in the less strongly developed antennæ ciliation, the less hairy labial palpi, and in the long-stalked veins 7 and 8 of the forewings.

\section{PLUMANA PIPERATELLA, new species.}

Plate 8, fig. 1.

Male.-Labial palpi blackish brown; face naked, black (possibly denuded). Antennæ yellowish. Head and thorax smoky white. Forewings smoky white with transverse striation of numerous blackish brown dots, which on the edges form a series of equidistant marginal spots all around the wing; a larger round brown dot at the end of the cell; posterior third of costa smoky brown. Cilia dirty white with a smoky brown line, parallel with the terminal edge. Hindwings smoky fuscous. Abdomen fuscous. Legs smoky white with the exterior surface fuscous.

Female.-Unknown, probably apterous.

Alar expanse. $-16-17 \mathrm{~mm}$.

Habitat.-St. Jean, Maroni River, French Guiana. Wm. Schaus, collector.

Type.-Cat. No. 13601, U.S.N.M.

Cotype in British Museum.

\section{EXPLANATION OF PLATES.}

\section{Plate 8.}

Fig. 1. Plumana piperatella Busck.

2. Stenoma io Busck.

3. Hasta argentidorsella Busck.

4. Stenoma gunni Busck.

5. Gonada falculinella Busck.

6. Stenoma lactis Busck.

7. Filinota hermosella Busck.

8. Stenoma major Busck.

9. Filinota peruviella Busck.

10. Stenoma fasciatum Busck.
Fig. 11. Stenoma comma Busck.

12. Pleurota literatella Busck.

13. Stenoma apicalis Busck.

14. Stenoma venatum Busck.

15. Peleopoda notandella Busck.

16. Peleopoda maroniella Busck.

17. Peleopoda irenella Busck.

18. Sienoma nestes Busck.

19. Stenoma acronitis Busck.

20. Stenoma mendoron Busck.

\section{Plate 9.}

Fig. 21. Olethreutes gerda Busck.

22. Stenoma thoristes Busck.

23. Stenoma maroni Busck.

24. Gonioterma emma Busck.

25. Ordrupia friserella Busck.

26. Gonioterma vita Busck.

27. Gonioterma anna Busck.

28. Gonioterma rosa Busck.

29. Goniotrma stella Busck.

30 Gonioierma inga Busck.

31. St noma speratum Busck.

32 S. noma vanis Busck.
Fig. 33. Stenoma inscitum Busck.

34. Stenoma trastices Busck.

35. Psoricoptera apicepuncta Busck.

36. Stenoma addon Busck.

37. Cryptolechia roseomarginella Busck.

38. Tortrix auriferana Busck.

39. Stenoma salome Busck.

40. Stenoma demas Busck.

41. Stenoma hamon Busck.

42. Stenoma phobe Busck.

43. Stenoma similis Busck. 


\section{$2 \mathrm{BHL}$ Biodiversity Heritage Library}

Busck, August. 1911. "Descriptions of tineoid moths (Microlepidoptera) from South America." Proceedings of the United States National Museum 40(1815), 205-230. https://doi.org/10.5479/si.00963801.40-1815.205.

View This Item Online: https://www.biodiversitylibrary.org/item/53820

DOI: https://doi.org/10.5479/si.00963801.40-1815.205

Permalink: https://www.biodiversitylibrary.org/partpdf/53272

\section{Holding Institution}

Smithsonian Libraries

\section{Sponsored by}

Smithsonian

\section{Copyright \& Reuse}

Copyright Status: Public domain. The BHL considers that this work is no longer under copyright protection.

This document was created from content at the Biodiversity Heritage Library, the world's largest open access digital library for biodiversity literature and archives. Visit BHL at https://www.biodiversitylibrary.org. 